\title{
Economic Diplomacy as A Subject and Research Agenda: Practical, Conceptual and Methodological Issue
}

\author{
Diplomasi Ekonomi Sebagai Kajian dan \\ Agenda Riset: Isu Praktis, Konseptual dan \\ Metodologis
}

\author{
Pantri Muthriana Erza Killian \\ Universitas Brawijaya
}

\begin{abstract}
ABSTRAK
Dalam kurun waktu 15-2o tahun terakhir, diplomasi ekonomi menjadi salah satu topik riset yang cukup diminati, seiring dengan semakin aktifnya negara-negara di dunia melakukan aktivitas ini. Australia, Jepang, Cina dan Indonesia merupakan contoh negaranegara yang telah melakukan restrukturisasi terhadap instrumen dan arah politik luar negeri untuk mengakomodasi masuknya diplomasi ekonomi sebagai salah satu agenda utama politik luar negerinya. Sayangnya, sebagai suatu kajian baru, diplomasi ekonomi masih mengalami beberapa tantangan utama, khususnya dalam proses pembentukan pengetahuan (knowledge-building process), yang ditandai dengan permasalahan pada tiga aspek utama yakni isu konseptual, metodologis dan alat analisis. Berdasarkan penelusuran terhadap referensi-referensi utamanya, tulisan ini menemukan bahwa diplomasi ekonomi masih membutuhkan konsolidasi di berbagai aspek termasuk definisi, varian/aliran, metode penelitian dan kerangka teori. Lebih lanjut, dikotomi antara studi diplomasi dan ilmu ekonomi - sebagai ilmu induk diplomasi ekonomi - juga menyebabkan polarisasi yang cukup signifikan dan berpengaruh pada perkembangannya sebagai bidang kajian. Oleh karena itu, tulisan ini bertujuan untuk mengusulkan upaya-upaya untuk mengatasi permasalahan-permasalahan ini dan membentuk diplomasi ekonomi sebagai suatu kajian dan agenda riset yang lebih tertata, sistematis, dan komprehensif.
\end{abstract}

Kata-kata kunci: diplomasi ekonomi, diplomasi, diplomasi dagang, diplomasi komersial

Within the last 15-20 years, economic diplomacy has emerged to become an intriguing research topic, in line with states' growing practice in this activity. Australia, Japan, China, and Indonesia are amongst the states who had restructured their instruments and foreign policy directions to incorporate economic diplomacy as an integral part of it. However, as a new research area, economic diplomacy faces several challenges in its knowledge-building process, most notably in formulating the conceptual, methodological, and analytical basis of the study. By tracing the core references of economic diplomacy, this paper finds that, as a research agenda, economic diplomacy lacks consolidation regarding its definition, variants/strands, research methods dan theoretical models. Moreover, the rigid dichotomy between diplomacy and economy - as the knowledge base of economic diplomacy - creates a significant polarisation, affecting economic diplomacy's development as a new research field. Therefore, this paper seeks to introduce ways to overcome these problems and develop economic diplomacy as a more systematic and comprehensive research agenda.

Keywords: economic diplomacy, diplomacy, trade diplomacy, commercial diplomacy 
Economic Diplomacy as A Subject and Research Agenda: Practical, Conceptual and Methodological Issue

Selama beberapa tahun terakhir, diplomasi ekonomi menjadi jargon yang cukup sering disebut, baik di media populer maupun dalam kajian ilmiah. Pencarian singkat di mesin telusur Google menghasilkan lebih dari satu juta entri untuk kata kunci economic diplomacy dan lebih dari 280.000 entri untuk kata 'diplomasi ekonomi', sedangkan pencarian melalui mesin telusur ilmiahnya - google scholar- menampilkan lebih dari 800.00o entri untuk economic diplomacy dan sekitar 23,000 entri untuk kata kunci 'diplomasi ekonomi'. Sebagai perbandingan, dalam kurun waktu 1990-2000, kata kunci economic diplomacy hanya menghasilkan 1.900 entri di google scholar, pencarian tahun 2000-2010 menghasilkan 4.900 entri dan pencarian 2010-2020 menghasilkan 13.000 entri yang menunjukkan peningkatan hampir tujuh kali lipat dalam kurun waktu 30 tahun terakhir. Popularitas diplomasi ekonomi juga bisa dilihat dalam praktik keseharian yang dilakukan oleh negara-negara di dunia, termasuk Indonesia. Sejak terpilihnya Presiden Joko Widodo (Jokowi) pada tahun 2014, diplomasi ekonomi 'naik kelas' menjadi salah satu pilar penting diplomasi Indonesia (Eldora 2020) dan kebijakan ini tetap dipertahankan di periode kedua kepemimpinan Jokowi melalui strategi diplomasi '4+1' yang diusung oleh Kementerian Luar Negeri (Tempo 2019). ${ }^{1}$ Bergesernya fokus diplomasi Indonesia ini tentunya tidak lepas dari tren global yang juga mulai bergerak ke arah diplomasi nontradisional, termasuk isu ekonomi.

Sejak akhir 1980an, negara-negara mulai menyadari pentingnya isu ekonomi dalam diplomasi dan mulai melakukan beberapa perubahan penting pada strategi kebijakan luar negerinya. Beberapa negara merestrukturisasi kementerian mereka dengan menambahkan atau menggabungkan fungsi ekonomi dalam kementerian luar negeri seperti yang dilakukan oleh Australia dengan membentuk Department of Foreign Affairs and Trade (DFAT) pada tahun 1987 (Australian Government Department of Foreign Affairs and Trade 2020a) dan Kanada yang mengesahkan Department of External Affairs and International Trade pada 1989 (Government of Canada 2019). Pada dasarnya restrukturisasi seperti ini merupakan respons dari perubahan eksternal yang

1 Strategi diplomasi ' $4+1$ ' merujuk pada empat prioritas utama diplomasi Indonesia yakni diplomasi ekonomi, diplomasi perlindungan WNI, diplomasi kedaulatan \& kebangsaan, diplomasi peran Indonesia di kawasan/global, serta satu elemen tambahan yang mengacu kepada penguatan infrastruktur diplomasi. 
secara global membuat fungsi ekonomi menjadi salah satu pilar penting dalam diplomasi negara. Pergeseran ini juga diikuti oleh dunia akademik yang secara bertahap mulai banyak melakukan kajian terkait diplomasi ekonomi, termasuk memunculkan diplomasi ekonomi sebagai suatu jurusan ataupun mata kuliah baru dalam kurikulum mereka. Beberapa kampus di Eropa dan Australia menawarkan jurusan/mata kuliah khusus diplomasi ekonomi ataupun diplomasi dagang (misal, London School of Economics \& Political Science, University of Birmingham, Monash University, dan Vrije Universiteit Brussel) dan beberapa kampus di Indonesia pun memunculkan peminatan atau mata kuliah khusus terkait diplomasi ekonomi (misal, Universitas Gadjah Mada, Universitas Indonesia, Universitas Andalas, dan Universitas Brawijaya).

Sayangnya, seiring dengan tren ini, masih terdapat banyak permasalahan terkait diplomasi ekonomi sendiri, baik sebagai sebuah praktik maupun sebagai agenda riset. Sebagai contoh, beberapa definisi utama terkait diplomasi ekonomi cenderung tidak seragam (lihat misal definisi oleh Bayne dan Woolcock 2012; Rana 2012; Okano-Heijmans 2016; van Bergeijk dan Moons 2018) dan bahkan aktivitas yang dapat dikategorikan sebagai diplomasi ekonomi pun cenderung tidak sama (lihat misal klasifikasi milik Rana 2007; Lee dan Hocking 2010; Okano-Heijmans 2011; Bayne dan Woolcock 2012). Negara-negara juga mempraktikkan diplomasi ekonomi mereka secara berbeda-beda sehingga cukup sulit untuk mendapatkan pemahaman yang universal mengenai apa itu diplomasi ekonomi. Sebagai contoh, Indonesia mempraktikkan diplomasi ekonomi melalui empat aktivitas utama yakni promosi dagang, promosi pariwisata, promosi investasi dan kerjasama pembangunan (Killian 2015). Negara lain, seperti Australia, fokus pada lima aktivitas yakni promosi investasi, penghapusan hambatan dagang non-tarif, pemberian dukungan dan fasilitasi bisnis, advokasi sistem global berbasis regulasi (rules-based system) serta peningkatan jaringan kerja sama inovasi sains dan teknologi (Australian Government Department of Foreign Affairs and Trade 2020b), sedangkan Jepang fokus pada tiga kegiatan utama yakni mendorong aturan global yang mendukung keterbukaan ekonomi, pemberian dukungan bagi perusahaan untuk ekspansi global dan promosi 'diplomasi sumber 
Economic Diplomacy as A Subject and Research Agenda: Practical, Conceptual and Methodological Issue

daya' serta inward investment ke Jepang (Ministry of Foreign Affairs Japan 2019).

Dari perspektif ilmiah, kerancuan ini memunculkan beberapa isu utama yakni adanya ketidakjelasan dalam penggunaan konsepkonsep dasar diplomasi ekonomi, adanya diskrepansi antara praktik dan teori diplomasi ekonomi serta isu metodologis terkait alat atau metode analisis dalam riset diplomasi ekonomi. Beberapa permasalahan ini menyebabkan sulitnya diplomasi ekonomi berkembang menjadi suatu bidang kajian dengan basis keilmuan yang kuat. Melihat tren ini, tulisan ini memiliki dua tujuan utama. Pertama, mengidentifikasi keterbatasan dari riset-riset diplomasi ekonomi yang saat ini ada serta tantangan-tantangan yang dihadapi. Kedua, menawarkan beberapa pemikiran dasar untuk memajukan kajian diplomasi ekonomi dan mendorong riset yang lebih komprehensif terkait ini, khususnya di Indonesia. Argumen utama yang ingin disampaikan adalah diplomasi ekonomi sebagai suatu agenda riset menghadapi tantangan dalam tiga hal utama yakni terkait isu konseptual, metodologis dan alat analisis. Secara lebih spesifik, isu ini berkaitan dengan definisi, varian, pendekatan, metode penelitian dan kerangka analisis dalam studi diplomasi ekonomi yang cenderung terkotak-kotak dan meminimalkan interaksi antara penstudi dengan latar belakang keilmuan yang berbeda. Oleh karena itu, tulisan ini mengusulkan tiga upaya untuk mendorong riset diplomasi ekonomi yang lebih sistematis dan membangun agenda riset yang lebih komprehensif.

Tulisan ini merupakan riset sekunder yang menggunakan kajian literatur (literature review) sebagai metode utamanya dan observasi untuk mengumpulkan beberapa data tambahan. Untuk mengelaborasi pemikiran ini, tulisan ini akan dibagi menjadi empat bagian. Bagian pertama menjabarkan tentang sejarah diplomasi ekonomi dan perkembangan kajiannya. Bagian kedua mengidentifikasi permasalahan-permasalahan utama dalam kajian diplomasi ekonomi. Bagian ketiga menawarkan pendekatan yang komprehensif dan aplikatif untuk melakukan riset diplomasi ekonomi. Bagian terakhir merupakan kesimpulan dan penutup. 


\section{Praktik Diplomasi Ekonomi: Aktivitas Lama dalam Perspektif Baru}

Meskipun secara praktik diplomasi ekonomi telah ada sejak lama, kajian komprehensif yang membahas mengenai diplomasi ekonomi masih sangat terbatas. Diplomasi ekonomi telah ada sejak era awal diplomasi terkait perang \& dagang atau classic war \& trade diplomacy (Okano-Heijmans 2011) dan pembentukan utusan-utusan dagang (trade emissaries) di zaman kekaisaran Ottoman bisa dianggap merupakan cikal bakal dari diplomasi ekonomi modern (Rana dan Chatterjee 2011). Di masa lampau, kapten kapal dari serikat dagang serupa East India Company milik Inggris dan Dutch East India Company milik Belanda diberikan kuasa untuk melakukan negosiasi dagang sebagai bagian dari ekspansi wilayah dan pasar nasional, yang menunjukkan aktivitas ekonomi sebagai bagian tidak terpisahkan dari diplomasi (Lee dan Hudson 2004). Di era modern, relasi ekonomi juga banyak mendominasi hubungan antar negara, seperti yang ditunjukkan oleh masifnya jumlah perjanjian ekonomi antar negara. ${ }^{2}$ Sebelum tahun 1980, negara-negara cenderung memisahkan antara fungsi politik luar negeri dan fungsi ekonomi internasionalnya karena menganggap diplomasi adalah isu politik tingkat tinggi (high politics) sedangkan isu ekonomi bukanlah isu high politics (Rana dan Chatterjee 2011). Aktivitas 'berjualan' dianggap bukan merupakan kewajiban seorang diplomat, meskipun secara praktik, diplomat modern menghabiskan cukup banyak waktu untuk mengelola relasi ekonomi antar negara.

Pemisahan ini menyebabkan diplomasi ekonomi jarang mendapatkan tempat dalam studi diplomasi karena terdapat dikotomi: antara apa yang disebut sebagai diplomasi 'tradisional' yang berorientasi kepada tujuan politik-keamanan seperti penjagaan wilayah dan kedaulatan, dengan diplomasi ekonomi yang fokus pada urusan dagang antar negara yang dianggap sebagai isu sekunder dalam dunia internasional. Salah satu alasan lain untuk ini adalah karena secara historis, diplomasi tradisional kerap dilakukan oleh kaum aristokrat atau bangsawan, sementara

2 Di bidang perdagangan saja, World Trade Organisation (WTO) melaporkan bahwa hingga kini ada lebih dari 600 perjanjian perdagangan bebas antara negara yang telah dilaporkan ke WTO (World Trade Organization 2019). 
Economic Diplomacy as A Subject and Research Agenda: Practical, Conceptual and Methodological Issue

aktivitas jual-beli dianggap sebagai pekerjaan 'rendahan' yang tidak seharusnya dikerjakan oleh kaum aristokrat (Lee dan Hudson 2004). Selain itu, dominasi dari teori-teori utama (mainstream) dalam kajian Hubungan Internasional yang fokus pada keamanan menyebabkan isu ekonomi sulit mendapatkan posisi dalam kajian utama diplomasi.

Selama beberapa dekade, diplomasi ekonomi terpinggirkan dalam studi diplomasi hingga akhirnya pada tahun 1980-1990-an, terjadi pergeseran dalam diskursus global dan isu ekonomi naik menjadi salah satu isu penting dalam relasi antarnegara. Berakhirnya Perang Dingin dan meningkatnya relasi ekonomi antarnegara secara masif mendorong negara-negara untuk menyesuaikan kebijakan luar negerinya, termasuk merestrukturisasi infrastruktur dan instrumen politik luar negerinya. Hal ini mendorong diplomasi ekonomi menjadi salah satu isu sentral dan kajian modern terkait diplomasi ekonomi mulai bermunculan. Beberapa karya-karya awal di masa ini termasuk Gardner (1985), van Bergeijk (1992), Stremlau (1994), Lee (1999) dan meskipun tidak secara spesifik menggunakan istilah 'diplomasi ekonomi', tulisan-tulisan ini memuat beberapa intisari dari kajian diplomasi ekonomi modern yang sekarang dikenal. ${ }^{3}$ Tahun 1990-2000-an bisa dikatakan merupakan 'era konsolidasi' dalam studi diplomasi ekonomi, yang ditandai dengan makin solidnya diplomasi ekonomi sebagai bidang kajian, khususnya karena beberapa kajian yang hampir serupa dengan diplomasi ekonomi juga mulai menemukan bentuk. Sebagai contoh, economic statecraft mulai digunakan untuk menjelaskan kajian yang menitikberatkan pada pencapaian tujuan politik luar negeri murni melalui aktivitas ekonomi (lihat misal Drezner 1999; Mastanduno 1999; Blanchard dan Ripsman 2008; Mastanduno 2012) dan Foreign Economic Policy (FEP) dipakai untuk menjelaskan kebijakan ekonomi negara yang hanya fokus pada dimensi ekonomi murni (Okamoto 1997). Sebelumnya, aktivitas-aktivitas ini kerap dimasukkan sebagai bagian dari diplomasi ekonomi sehingga memunculkan kerancuan. Pembedaan ini secara bertahap mulai membentuk diplomasi

3 Beberapa studi pada masa ini menggunakan istilah diplomasi komersial, diplomasi dagang, diplomasi dolar dan kebijakan ekonomi luar negeri (foreign economic policy) untuk menjelaskan ragam aktivitas dari diplomasi ekonomi era modern 
ekonomi menjadi suatu kajian baru, meskipun secara konseptual dan metodologis masih memiliki beberapa keterbatasan.

Tahun 2000 hingga sekarang menandai perkembangan pesat dari kajian diplomasi ekonomi, seiring dengan praktik negara-negara yang juga mulai meningkat. Banyak literatur pada masa ini yang berupaya memberikan definisi yang lebih jelas dan kerangka konseptual yang bisa digunakan untuk mengkaji diplomasi ekonomi (lihat misal Saner dan Yiu 2003; Yakop dan Van Bergeijk 2009; Lee dan Hocking 2010; Okano-Heijmans 2011; Woolcock 2012; Bayne dan Woolcock 2012; Rana 2012). Buku-buku teks utama terkait ini pun mulai diterbitkan, di antaranya The New Economic Diplomacy: Decision making and Negotiation in International Economic Relations (2003, 2007, 2012); Economic Diplomacy: Economic and Political Perspectives (2011); dan Research Handbook on Economic Diplomacy (2018); termasuk lahirnya jurnal ilmiah pertama yang fokus pada studi diplomasi ekonomi -International Journal of Diplomacy and Economy (IJDipE) - yang terbit pada tahun 2012. Buku-buku teks utama diplomasi pun mulai memasukkan 'Diplomasi Ekonomi' sebagai salah satu topik kajian di dalamnya, seperti di buku Oxford Handbook of Modern Diplomacy (2013) dan Sage Handbook of Diplomacy (2016), yang menandai masuknya isu ekonomi sebagai salah satu kajian mainstream di diplomasi. Era ini juga memunculkan beberapa proponen-proponen utama kajian ini, di antaranya Peter van Bergeijk, Nicholas Bayne, Stephen Woolcock, Kishan Rana dan Maaike Okano-Heijmans.

Dari paparan di atas, bisa dilihat bahwa secara historis, diplomasi ekonomi bukanlah sebuah praktik baru, meskipun secara keilmuan bisa dikatakan sebagai sebuah kajian baru yang bergantung kepada beberapa pemikiran lama. Praktik diplomasi ekonomi juga cenderung mengalami fase naik-turun, di mana peristiwa global tertentu bisa menaikkan (atau menurunkan) 'status' isu ekonomi sebagai permasalahan sentral dalam hubungan antarnegara. Sebagai contoh, diplomasi Dollar (Dollar diplomacy) -yang merupakan salah satu bentuk klasik diplomasi ekonomi- menjadi sentral dalam politik luar negeri AS di masa Presiden Howard S. Tuft (1909-1913), namun cenderung kurang dominan di masamasa setelahnya. Cina di masa sekarang juga identik dengan praktik 
Economic Diplomacy as A Subject and Research Agenda: Practical, Conceptual and Methodological Issue

diplomasi buku cek (Checkbook Diplomacy), yang mengaitkan bantuan luar negeri dengan tujuan politik dan keamanan, setelah sebelumnya, Jepang dianggap menjalankan kebijakan serupa. Menurut Mastanduno (1998), struktur politik-keamanan global sangat berpengaruh terhadap relasi ekonomi antarnegara. Sistem unipolar dan multipolar akan menyebabkan relasi ekonomi antarnegara untuk meningkat karena interaksi ekonomi berfungsi sebagai 'pengikat' yang digunakan oleh negara dominan di struktur unipolar dan sebagai 'magnet' oleh negara-negara yang ingin berkuasa di struktur multipolar. Sebaliknya, struktur bipolar akan menyebabkan relasi ekonomi untuk berkurang karena kedua kubu akan cenderung independen dan membatasi relasi ekonomi di antara mereka. Asumsi ini, khususnya terkait struktur multipolar, cenderung sejalan dengan argumen Coolsaet (2001; 2004) yang melihat bahwa diplomasi ekonomi akan cenderung meningkat ketika globalisasi tidak diimbangi dengan regulasi yang cukup karena negara-negara akan menggunakan diplomasi ekonomi untuk 'mengawal' kepentingan ekonomi mereka di sistem yang anarki. Dengan kata lain, meningkatnya diplomasi ekonomi di masa sekarang, baik sebagai praktik maupun bidang kajian, tidak lepas dari perubahan di struktur global yang bergeser ke arah multipolar (dan multiaktor), dibarengi dengan lemahnya regulasi di tingkat internasional yang memaksa negara-negara untuk beradaptasi dan bergantung kepada strategi individual melalui diplomasi ekonomi.

Oleh karena itu, meskipun secara praktik, diplomasi ekonomi bukanlah hal baru, ketertarikan terhadap isu ini cenderung tidak konstan dan sedikit berulang (cyclical), dengan penggunaan istilah yang berbeda-beda di tiap era sehingga kerap membingungkan. Kecenderungan ini memunculkan beberapa tantangan utama untuk mengembangkan diplomasi ekonomi sebagai suatu kajian ilmu yang independen.

\section{Diplomasi Ekonomi Sebagai Agenda Riset: Tantangan Konseptual dan Metodologis}

Secara etimologis, diplomasi ekonomi terdiri dari dua kata diplomasi dan ekonomi. Keduanya berakar dari bidang ilmu yang 
memiliki ontologi (dan terkadang, epistemologi) yang berbeda. Diplomasi berakar dari kajian politik luar negeri, dengan fokus utama distribusi kekuasaan di tingkat global, sedangkan ilmu ekonomi fokus pada distribusi kekayaan, baik di tingkat lokal maupun global. Hal ini menyebabkan adanya tarik-ulur dan kerancuan dalam melihat diplomasi ekonomi, yakni apakah ia merupakan bagian dari aktivitas diplomasi, aktivitas ekonomi atau keduanya? Lantas jika keduanya, bagaimana batasan dan pembagian di antaranya? Secara lebih spesifik, perbedaan sudut pandang ini memunculkan tiga tantangan utama dalam mengkaji diplomasi ekonomi, yakni perdebatan konseptual, isu metodologis dan permasalahan tingkat kajian.

Isu konseptual berkaitan dengan dua aspek yakni bagaimana diplomasi ekonomi didefinisikan dan apa batasan diplomasi ekonomi dalam suatu riset. Untuk definisi sendiri, terdapat banyak varian tentang arti 'diplomasi ekonomi'. Sebagai contoh, diplomasi ekonomi bisa didefinisikan sebagai suatu 'strategi' (Okano-Heijmans 2011; 2016), 'kebijakan' (Berridge dan James 2003), 'proses' (Rana dan Chatterjee 2011; Rana 2012; Bayne dan Woolcock2012), ataupun 'aktivitas'(van Bergeijkdan Moons 2009). Masing-masing definisi ini memiliki pemaknaan dan implementasi yang berbeda-beda. Hal ini juga diikuti dengan perbedaan dalam memahami tujuan dari diplomasi ekonomi, yakni apakah untuk tujuan akhir ekonomi atau komersial (Rana dan Chatterjee 2011), tujuan politik luar negeri (Berridge dan James 2003), atau tujuan ekonomi dan politik (Okano-Heijmans 2016; van Bergeijk dan Moons 2018). Dalam bagian pengantar di buku kompilasi Research Handbook of Economic Diplomacy (2018), van Bergeijk tidak memberikan definisi spesifik mengenai diplomasi ekonomi, namun hanya mengkategorikannya menjadi multilateral dan nonmultilateral economic diplomacy dan diplomasi ekonomi positif dan negatif (van Bergeijk 2018, 1-3). Lebih lanjut, van Bergeijk juga menyatakan bahwa tulisan lain di dalam buku tersebut akan mendefinisikan dan mengkategorikan diplomasi ekonomi dengan cara yang mungkin berbeda dikarenakan titik awal yang mungkin berlainan (van Bergeijk 2018, 3). Hal ini menunjukkan belum adanya keseragaman definisi diplomasi ekonomi secara keilmuan, bahkan dalam suatu karya bersama. 
Economic Diplomacy as A Subject and Research Agenda: Practical, Conceptual and Methodological Issue

Tantangan berikutnya dari segi konseptual adalah terkait batasan dari apa yang bisa dikategorikan sebagai 'diplomasi ekonomi'. Selama kurun waktu hampir 30 tahun, terdapat banyak variasi dalam menjelaskan ragam aktivitas ataupun proses yang termasuk diplomasi ekonomi seperti promosi dagang, negosiasi Free Trade Agreement (FTA), sanksi ekonomi, hingga pemberian bantuan luar negeri. Hal ini memunculkan banyak kerancuan karena meskipun banyak peneliti yang secara bersama-sama menggunakan istilah 'diplomasi ekonomi' dalam risetnya, seringkali hal yang mereka maksud tidaklah sama. Beberapa penstudi kemudian mengusulkan perlunya pembagian aliran/varian (strand) dalam diplomasi ekonomi, untuk memperjelas batasan studi yang akan dilakukan. Beberapa pembagian varian yang muncul dalam studi diplomasi ekonomi antara lain sebagai berikut:

Tabel 1

Aliran/Varian dalam Kajian Diplomasi Ekonomi

\begin{tabular}{|c|c|c|c|}
\hline \multirow{2}{*}{$\begin{array}{c}\text { Varian } \\
\text { Diplomasi } \\
\text { Ekonomi }\end{array}$} & \multicolumn{3}{|c|}{ Jenis Aktivitas/Instrumen yang Digunakan } \\
\hline & $\begin{array}{c}\text { Lee \& Hocking } \\
(2010)\end{array}$ & $\begin{array}{c}\text { Rana \& } \\
\text { Chatterjee } \\
(\mathbf{2 0 1 1})\end{array}$ & $\begin{array}{c}\text { Okano-Heijmans } \\
\text { (2011) }\end{array}$ \\
\hline $\begin{array}{l}\text { Diplomasi } \\
\text { Dagang } \\
\text { (Trade } \\
\text { Diplomacy) }\end{array}$ & $\begin{array}{l}\text { Formulasi } \\
\text { regulasi } \\
\text { perdagangan } \\
\text { global }\end{array}$ & $\begin{array}{l}\text { Formulasi } \\
\text { regulasi } \\
\text { perdagangan } \\
\text { global, } \\
\text { perjanjian } \\
\text { dagang (FTA/ } \\
\text { RTA) }\end{array}$ & $\begin{array}{l}\text { Formulasi regulasi } \\
\text { perdagangan di } \\
\text { tingkat bilateral \& } \\
\text { multilateral; negosiasi } \\
\text { tarif, kuota, investasi, } \\
\text { lisensi ekspor-impor } \\
\text { dan hambatan dagang } \\
\text { lainnya }\end{array}$ \\
\hline $\begin{array}{l}\text { Diplomasi } \\
\text { Komersial } \\
\text { (Commercial } \\
\text { Diplomacy) }\end{array}$ & $\begin{array}{l}\text { Promosi } \\
\text { dagang; promosi } \\
\text { investasi; } \\
\text { promosi } \\
\text { pariwisata }\end{array}$ & $\begin{array}{l}\text { Promosi } \\
\text { dagang; promosi } \\
\text { investasi; } \\
\text { dukungan bisnis } \\
\text { \& pembentukan } \\
\text { jaringan lokal/ } \\
\text { global; nation- } \\
\text { branding }\end{array}$ & $\begin{array}{l}\text { Promosi dagang; } \\
\text { promosi investasi; } \\
\text { advokasi bisnis; } \\
\text { promosi pariwisata; } \\
\text { promosi investasi } \\
\text { yang berkelanjutan }\end{array}$ \\
\hline
\end{tabular}




\begin{tabular}{|c|c|c|c|}
\hline $\begin{array}{l}\text { Diplomasi } \\
\text { Finansial } \\
\text { (Financial } \\
\text { Diplomacy) }\end{array}$ & $\begin{array}{l}\text { Pembentukan } \\
\text { (dan kegagalan) } \\
\text { institusi } \\
\text { finansial global }\end{array}$ & $\begin{array}{l}\text { Formulasi } \\
\text { regulasi } \\
\text { finansial global }\end{array}$ & $\begin{array}{l}\text { Perjanjian pertukaran } \\
\text { mata uang (currency } \\
\text { swap agreements); } \\
\text { kebijakan nilai } \\
\text { tukar; penjualan \& } \\
\text { pembelian surat utang } \\
\text { negara; pembekuan } \\
\text { aset; penundaan/ } \\
\text { penahanan } \\
\text { pembayaran }\end{array}$ \\
\hline $\begin{array}{l}\text { Aktivitas } \\
\text { Konsuler } \\
\text { (Consular } \\
\text { Activities) }\end{array}$ & $\begin{array}{l}\text { Pengaturan lalu } \\
\text { lintas manusia } \\
\text { lintas negara }\end{array}$ & - & - \\
\hline $\begin{array}{l}\text { Sanksi Negatif } \\
\text { (Negative } \\
\text { Sanctions) }\end{array}$ & - & - & $\begin{array}{l}\text { Embargo; boikot; } \\
\text { penangguhan } \\
\text { bantuan luar negeri; } \\
\text { pengendalian modal } \\
\text { (capital controls); } \\
\text { penyusunan daftar } \\
\text { hitam (blacklist) }\end{array}$ \\
\hline $\begin{array}{l}\text { Insentif Positif } \\
\text { (Positive } \\
\text { Inducements) }\end{array}$ & - & - & $\begin{array}{l}\text { Bantuan luar negeri } \\
\text { (hibah, pinjaman, } \\
\text { penghapusan } \\
\text { hutang, bantuan } \\
\text { kemanusiaan); } \\
\text { pemberiaan akses } \\
\text { teknologi; pemberian } \\
\text { keanggotaan } \\
\text { di organisasi } \\
\text { internasional }\end{array}$ \\
\hline
\end{tabular}

Sumber: Kompilasi Penulis

Dari tabel di atas, dapat dilihat bahwa secara pembagian, terdapat dua varian diplomasi ekonomi yang memiliki batasan dan jenis aktivitas yang cukup jelas yakni diplomasi dagang dan diplomasi komersial. Para penstudi cenderung memiliki persepsi yang sama mengenai batasan aktivitasnya dan secara umum, dua varian inilah yang paling maju dari segi riset. Diplomasi komersial banyak diteliti oleh penstudi dengan latar keilmuan ekonomi dan pengetahuan kuantitatif yang kuat, sedangkan diplomasi dagang banyak dikaji oleh penstudi politik dengan berbasis kajian kualitatif dan studi kasus. Namun perlu dicatat juga bahwa beberapa penstudi kerap menggunakan istilah 'diplomasi ekonomi', meskipun hanya 
Economic Diplomacy as A Subject and Research Agenda: Practical, Conceptual and Methodological Issue

menjelaskan diplomasi komersial ataupun diplomasi dagang (dan bukan keseluruhan aktivitas) sehingga kerancuan konseptual ini masih tetap ada. Oleh karena itu, perlu ada kehati-hatian dalam penggunaan istilah diplomasi ekonomi dalam suatu riset. Selain varian diplomasi ekonomi di atas, beberapa penstudi juga menambahkan isu baru dalam diplomasi ekonomi, seperti Woolcock (2012a) yang memasukkan isu lingkungan sebagai salah satu varian dalam diplomasi ekonomi dan Lee dan Hudson (2004) yang memasukkan lalu lintas manusia sebagai tambahan varian lain. Dalam perkembangannya, negara-negara di dunia saat ini cenderung fokus ke tiga praktik utama diplomasi ekonomi yakni diplomasi dagang, diplomasi komersial dan diplomasi bantuan luar negeri (Okano-Heijmans 2016).

Tantangan kedua dalam riset diplomasi ekonomi adalah terkait metodologi atau bagaimana riset dijalankan sesuai kaidah ilmiah. Secara keilmuan, diplomasi ekonomi bisa dikaji dari dua bidang ilmu, yakni diplomasi dan ekonomi, yang masingmasing merupakan bidang studi tersendiri dan memiliki ontologi dan epistemologi yang berbeda. Diplomasi fokus pada relasi antarnegara dalam kerangka yang terinstitusionalisasi, sedangkan ekonomi fokus pada produksi, distribusi dan konsumsi sumber daya yang terbatas, dan diplomasi ekonomi berada di antara kedua bidang kajian ini. Posisi ini menempatkan diplomasi ekonomi sebagai bidang studi yang bersifat interdisipliner dan dalam kelanjutannya, memunculkan beberapa tantangan utama. Ini sedikit berbeda dengan varian diplomasi lain seperti diplomasi pertahanan, misalnya, yang berada di spektrum kajian ilmu yang cenderung berdekatan. Secara khusus, permasalahan metodologi ini bisa dipecah menjadi dua isu, yakni perbedaan dalam pendekatan (approach) dan keterbatasan dalam alat analisis.

Perbedaan pendekatan dalam bidang ilmu pada dasarnya bukan sebuah permasalahan dalam pengertian seutuhnya, tapi lebih merupakan tantangan yang perlu dipertimbangkan sebelum melakukan riset terkait diplomasi ekonomi. Karena posisinya yang berada di antara diplomasi dan ekonomi, diplomasi ekonomi kerap dipelajari dari berbagai bidang ilmu, yang meskipun membuatnya lebih kaya secara keilmuan, hal ini terkadang cukup membingungkan ketika dipraktikkan. Diplomasi ekonomi 
biasanya dikaji melalui ilmu ekonomi atau ilmu politik, dan tiap bidang kajian ini pun bisa dijabarkan lebih lanjut menjadi beberapa cluster atau sub-cluster lain. Sebagai contoh, ilmu ekonomi bisa dipecah menjadi pendekatan berbasis makroekonomi, manajemen, ataupun bisnis. Pendekatan dari segi politik pun masih bisa dipecah menjadi sub-cluster hubungan internasional, ekonomi politik internasional, kebijakan luar negeri, diplomasi dan negosiasi yang menunjukkan banyaknya cluster disiplin ilmu atau studi yang menjadikan diplomasi ekonomi sebagai salah satu kajiannya. Namun untuk simplifikasi, tulisan ini hanya mengidentifikasi dua cluster besar untuk pembahasan yang lebih ringkas. ${ }^{4}$

Penstudi diplomasi ekonomi dari pendekatan ekonomi cenderung menggunakan analisis berbasis kuantitatif dalam analisisnya, yang sejalan dengan pendekatan umum di bidang ilmu ini. Beberapa penstudi utamanya antara lain, Peter van Bergeijk, Selwyn Moons, dan Olivier Naray. Fokus studi kelompok ini adalah pada dampak dari keberadaan perwakilan luar negeri (seperti kedutaan, konsulat, misi dagang, dll) terhadap arus ekspor/impor ke/dari suatu negara, yang menandai kuatnya aspek makroekonomi dan ilmu ekonomi internasional di dalamnya (lihat misal Yakop dan Van Bergeijk 2011; Naray 2011; Moons dan van Bergeijk 2017; Moons 2017). Di sisi yang lain, pengkaji diplomasi ekonomi yang berbasis pendekatan politik (dan kajian turunannya) cenderung bergantung kepada penggunaan analisis kualitatif dan studi kasus untuk menjelaskan diplomasi ekonomi. Proponen pendekatan ini lebih banyak fokus pada aspek negosiasi dan dimensi politik atau keamanan dari diplomasi ekonomi sehingga menawarkan lingkup atau basis data yang lebih kecil, namun kajian yang kerap lebih mendalam (lihat misal Bayne 2012; Woolcock 2012a; OkanoHeijmans 2012).

Kuatnya dikotomi antara ekonomi dan politik ini sesungguhnya tidaklah terlalu mengherankan dan bisa dikatakan merupakan isu lama, khususnya dalam kajian Hubungan Internasional. Dalam

4 Beberapa penstudi lain melakukan pengelompokkan yang lebih detail, seperti OkanoHeijmans yang mengidentifikasi empat cluster ilmu yang berkontribusi dalam kajian diplomasi ekonomi yakni Hubungan Internasional, Ilmu Ekonomi, Ekonomi Politik Internasional dan Diplomasi-Negosiasi (Okano-Heijmans 2011). 
tulisannya, International Economics and International Relations: A Case of Mutual Neglect, Susan Strange (1970) menjelaskan permasalahan klasik ini dengan mengelaborasi pengabaian (neglect) yang sama-sama dilakukan oleh penstudi Ekonomi Internasional dan Hubungan Internasional. Penstudi Ekonomi Internasional cenderung abai terhadap struktur kekuasaan global sehingga penjelasannya terkadang bersifat parsial dan sebaliknya, pengkaji Hubungan Internasional kurang memiliki basis pengetahuan ekonomi yang kuat karena fokusnya yang terlalu dominan pada distribusi kekuasaan global. Pemikiran ini memelopori lahirnya kajian Ekonomi Politik Internasional yang kini telah berkembang menjadi bidang studi tersendiri.

Sayangnya, riset diplomasi ekonomi juga cenderung mengalami dikotomi ini karena tiap kelompok penstudi fokus pada varian diplomasi ekonomi yang berbeda dan menggunakan landasan epistemologis dan metodologis yang cenderung terpisah sehingga memunculkan kesulitan untuk memunculkan kerangka analisis riset yang 'murni' dan bukan dipinjam dari bidang ilmu lain. Meskipun terdapat beberapa buku diplomasi ekonomi yang menggabungkan kajian ekonomi dan politik secara bersamaan seperti buku Economic Diplomacy: Economic and Political Perspectives (2011) dan Research Handbook on Economic Diplomacy (2018), kedua pendekatan ini biasanya ditulis dalam bab yang terpisah dan tidak digunakan secara bersamaan. Selain itu, sangat jarang ditemukan riset diplomasi ekonomi yang menggunakan metode campuran (mixed methods) yang juga menunjukkan sangat minimnya kolaborasi antara penstudi kuantitatif dan kualitatif di bidang ini. Minimnya kolaborasi ini memunculkan masalah selanjutnya terkait metodologi, yakni terbatasnya kerangka analisis yang holistik dan aplikatif dalam studi diplomasi ekonomi. Menilik riset diplomasi ekonomi selama beberapa dekade terakhir, tercatat hanya ada kurang dari lima kerangka analisis yang murni diambil dari kajian diplomasi ekonomi dan bukan dipinjam dari bidang ilmu lain. ${ }^{5}$ Beberapa publikasi diplomasi ekonomi meminjam kerangka analisis dari Ilmu Ekonomi (lihat misal Chen dan Garcia 2016; Moons dan

5 Kerangka analisis disini diartikan sebagai kerangka konseptual yang fokus pada sisi deskriptif (penggambaran tanpa menjelaskan relasi) dan kerangka teoritik yang fokus pada sisi eksplanatif (penggambaran dengan menjelaskan relasi). 
van Bergeijk 2017; Moons, 2017), Ilmu Politik/studi Hubungan Internasional (lihat misal Zeng 2016; Mdunge 2018) atau kajian diplomasi/negosiasi (lihat misal Rana 2007; Okano-Heijmans 2012; Selmier dan Oh 2013).

Hingga kini, tercatat hanya ada tiga penstudi yang menawarkan kerangka murni untuk mengkaji diplomasi ekonomi, yakni Stephen Woolcock dalam kajiannya tentang praktik diplomasi ekonomi Uni Eropa, Okano-Heijmans yang menjelaskan praktik diplomasi ekonomi Jepang, dan Kishan Rana yang menawarkan tipologi diplomasi ekonomi negara berkembang. Di antara ketiga kerangka ini, Woolcock menawarkan kerangka yang cenderung berbeda karena fokus pada organisasi regional sebagai aktor diplomasi ekonomi dan bukan negara seperti pada dua kerangka analisis lainnya. Sayangnya, kerangka-kerangka analitis ini masih terbatas karena belum banyak studi-studi lain yang menggunakannya sehingga penerapannya (applicability) pun cenderung masih terbatas. Beberapa kerangka juga cenderung membingungkan, seperti milik Okano-Heijmans, sehingga sulit untuk menentukan titik awal dan titik akhir dari analisis (Bayne 2014). Munculnya kerangka-kerangka analitis ini menandai semakin berkembangnya diplomasi ekonomi sebagai suatu kajian, namun di sisi lain, terbatasnya penerapan dan penggunaan dari kerangka-kerangka ini menunjukkan satu kelemahan lain, yakni terdapat gap antara fenomena dan kerangka penjelasannya. Sebagai contoh, kerangka milik Woolcock mengidentifikasi normative power sebagai salah satu faktor yang mempengaruhi diplomasi ekonomi Uni Eropa (Woolcock, 2012a), namun sayangnya normative power ini cenderung masih eksklusif untuk Uni Eropa dan jarang ditemukan di organisasi regional lain. Hal ini menyebabkan kekuatan penjelasan (explanatory power) dari kerangka-kerangka ini menjadi terbatas.

Tantangan ketiga dan terakhir dalam riset diplomasi ekonomi adalah terkait tingkat kajian, atau di level mana riset tersebut difokuskan. Secara umum, relasi antar negara dapat dibagi menjadi dua kelompok besar yakni relasi bilateral, yang melibatkan dua negara dan relasi multilateral, yang melibatkan lebih dari dua negara. Untuk relasi ekonomi sendiri, tingkatan ini bisa diturunkan menjadi lebih detail dengan menambahkan 
Economic Diplomacy as A Subject and Research Agenda: Practical, Conceptual and Methodological Issue

dua tingkatan lain yakni relasi ekonomi regional, yang mencakup aktivitas ekonomi yang dibatasi oleh lingkup kawasan dan relasi ekonomi plurilateral, yang merupakan aktivitas ekonomi eksklusif yang terbatas hanya untuk beberapa negara. ${ }^{6}$ Perbedaan dari masing-masing tingkatan dapat dilihat di tabel berikut:

Tabel 2

Tingkatan dan Taksonomi Dasar Diplomasi Ekonomi

\begin{tabular}{|l|c|c|c|c|}
\hline & Bilateral & Regional & Plurilateral & Multilateral \\
\hline $\begin{array}{l}\text { Terbuka bagi } \\
\text { semua negara }\end{array}$ & $\checkmark$ & - & - & $\checkmark$ \\
\hline $\begin{array}{l}\text { Hanya terbuka } \\
\text { bagi negara } \\
\text { tertentu }\end{array}$ & - & $\checkmark$ & $\checkmark$ & - \\
\hline $\begin{array}{l}\text { Membutuhkan } \\
\text { organisasi }\end{array}$ & - & $\checkmark$ & $\checkmark$ & $\checkmark$ \\
\hline $\begin{array}{l}\text { Disukai oleh } \\
\text { negara besar }\end{array}$ & $\checkmark$ & - & - & - \\
\hline $\begin{array}{l}\text { Disukai oleh } \\
\text { negara sedang }\end{array}$ & - & $\checkmark$ & $\checkmark$ & - \\
\hline $\begin{array}{l}\text { Disukai oleh } \\
\text { negara kecil }\end{array}$ & - & - & - & $\checkmark$ \\
\hline
\end{tabular}

Sumber: Bayne (2012)

Adanya variasi relasi ekonomi antarnegara ini menyebabkan perlunya perhatian khusus terkait tingkat analisis ketika melakukan riset diplomasi ekonomi karena peneliti perlu menspesifikkan di tingkat mana penelitian akan dilakukan. Sebagai contoh, praktik diplomasi dagang yang dilakukan di tingkat bilateral akan berbeda dengan diplomasi dagang multilateral, bukan hanya karena jumlah peserta, tapi juga adanya perbedaan strategi seperti pembentukan koalisi yang hanya bisa dilakukan di tingkat multilateral. Diplomasi regional dan plurilateral juga memiliki karakteristik yang berbeda sehingga perlu ada distingsi yang jelas terkait tingkat analisis dalam melakukan penelitian diplomasi ekonomi.

6 Beberapa contoh dari kerjasama ekonomi plurilateral adalah Organisation for Economic Cooperation and Development (OECD), Organisation of the Petroleum Exporting Countries (OPEC) dan Group of Twenty (G-20). 


\section{Membangun Riset Diplomasi Ekonomi yang Sistematis dan Komprehensif}

Dari pemaparan di atas, dapat dilihat adanya beberapa isu praktis, konseptual dan metodologis yang perlu dipertimbangkan dalam melakukan riset diplomasi ekonomi. Penjabaran isu-isu ini perlu dilakukan secara detail sebelum melakukan riset mengingat masih 'kusutnya' riset diplomasi ekonomi secara umum sehingga perlu adanya upaya untuk merapikan diplomasi ekonomi sebagai agenda riset yang berkelanjutan. Berdasarkan klasifikasi ini pula, tulisan ini mengusulkan tiga upaya utama yang bisa dilakukan untuk mengembangkan diplomasi ekonomi menjadi agenda riset yang lebih terstruktur dan komprehensif.

Pertama, perlu adanya upaya untuk menghasilkan penelitianpenelitian diplomasi ekonomi yang lebih fokus dengan memberikan definisi, klasifikasi dan dikotomi yang jelas. Dari paparan sebelumnya, bisa dilihat bahwa setidaknya ada lima pertimbangan utama yang perlu diambil sebelum melakukan riset diplomasi ekonomi yakni terkait definisi yang digunakan, aliran/ varian yang diteliti, tingkat kajian yang menjadi fokus, pendekatan yang dipilih dan metode penelitian yang digunakan. Ilustrasi dan penjabaran dari kelima elemen ini bisa dilihat di bagan berikut:

\section{Bagan 1}

\section{Klasifikasi Elemen-Elemen Utama dalam Riset Diplomasi Ekonomi}
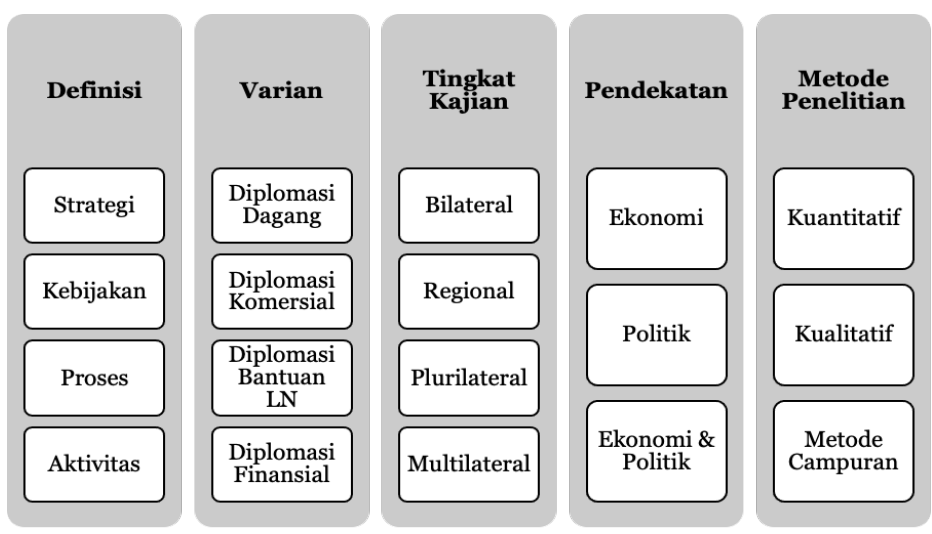

Sumber: Kompilasi Penulis 
Economic Diplomacy as A Subject and Research Agenda: Practical, Conceptual and Methodological Issue

Bagan di atas bisa membantu menentukan fokus riset diplomasi ekonomi dan berdasarkan bagan tersebut, ada tiga tahapan utama yang perlu diperhitungkan sebelum melakukan riset diplomasi ekonomi. Tahap pertama adalah memberikan definisi yang jelas mengenai diplomasi ekonomi, yakni sebagai strategi, kebijakan, proses atau aktivitas. Klasifikasi di atas dihasilkan dari definisi yang diusulkan oleh studi-studi terdahulu, namun tidak menutup kemungkinan munculnya definisi baru sesuai riset yang dilakukan. Tahap kedua adalah mengidentifikasi varian atau jenis diplomasi ekonomi yang akan diteliti dan mengidentifikasi di tingkat mana penelitian akan difokuskan. Tentu saja penelitian dapat mencakup semua varian dan/atau dilakukan di semua tingkatan, namun klasifikasi ini mempermudah proses pemilahan dan analisis data sehingga bisa menghasilkan riset yang lebih detail dan komprehensif. Tahap ketiga adalah menentukan pendekatan dan metode penelitian yang akan digunakan, baik berupa pendekatan ekonomi, politik atau ekonomi-politik maupun metode kuantitatif, kualitatif ataupun campuran. Pemilihan pendekatan ini juga sangat berkaitan erat dengan kerangka atau alat analisis yang digunakan dalam penelitian.

Setelah seluruh pilihan-pilihan ini ditentukan, penelitian bisa 'diuraikan' dengan lebih jelas, guna proses pencarian data dan analisis yang lebih terstruktur. Sebagai contoh, riset tentang diplomasi dagang Indonesia-sebagai bagian dari diplomasi ekonomi-bisa dijelaskan dengan mendefinisikannya sebagai strategi Indonesia di tingkat bilateral, regional, plurilateral, dan multilateral dengan menggunakan pendekatan kualitatif. Sebaliknya, efektivitas diplomasi komersial Indonesia bisa diartikan sebagai aktivitas negara dan diteliti dengan metode kuantitatif (atau metode campuran) di tingkat bilateral (atau tingkat lainnya) untuk melihat ada tidaknya variasi dalam pemenuhan tujuan diplomasi tersebut. Kombinasi dari berbagai elemen ini akan menghasilkan penelitian yang lebih fokus, terukur dan di waktu bersamaan, dapat mengurai kusutnya riset diplomasi ekonomi secara umum.

Kedua, untuk mengatasi keterbatasan dari kerangka analisis (konsep/teori/model) diplomasi ekonomi, perlu adanya penggunaan dan perbaikan yang lebih luas dari alat analisis yang 
telah ada dan di waktu bersamaan menginisiasi riset-riset induktif berbasis data untuk memunculkan kerangka analisis baru yang dirasa perlu. Banyaknya variasi praktik antarnegara-seperti yang ditunjukkan oleh perbedaan antara Indonesia, Australia, dan Jepang-menunjukkan masih perlunya upaya untuk melakukan konseptualisasi dan generalisasi dari praktik-praktik ini yang berarti, masih sangat luasnya peluang riset untuk bidang ini. Sebagai contoh, Rana (2012) memperkenalkan tipologi diplomasi ekonomi negara berkembang yang cenderung berbeda dengan negara maju sehingga memerlukan konseptualisasi tersendiri. Sejalan dengan ini, Okano-Heijmans (2016) juga mengidentifikasi perbedaan tujuan diplomasi ekonomi antara negara maju dan negara berkembang dan menyimpulkan bahwa cukup sulit untuk mengadopsi satu pendekatan universal (one-size-fits-all approach) dalam studi diplomasi ekonomi yang menunjukkan bahwa masih dibutuhkan banyak penelitian terkait diplomasi ekonomi, khususnya untuk menjelaskan praktik-praktik yang distingtif.

Ketiga, diperlukan upaya untuk mendorong dan memperbanyak riset interdisipliner dan penggunaan metode campuran (mixed methods) untuk menghasilkan riset yang lebih komprehensif dan detail. Dalam paparan sebelum ini, dapat dilihat bahwa adanya dikotomiantarapolitikdan ekonomicenderungmemisahkanantara penstudi diplomasi ekonomi dengan basis keilmuan ekonomi dan politik sehingga riset yang dihasilkan pun cenderung terkotakkotak. Kolaborasi yang lebih intensif antara penstudi dengan latar belakang keilmuan berbeda akan membantu memajukan riset diplomasi ekonomi karena akan menawarkan hasil penelitian yang lebih kaya dan luas. Sebagai contoh, riset diplomasi komersial berbasis pendekatan kuantitatif, bisa dilengkapi juga dengan analisis strategi komunikasi internasional yang berbasis penelitian kualitatif untuk menghasilkan output riset yang lebih aplikatif. Hal ini juga berlaku untuk riset terkait diplomasi dagang, diplomasi finansial, dan diplomasi bantuan luar negeri yang bisa menggabungkan bukan hanya beberapa pendekatan keilmuan, tapi juga beberapa metode penelitian. Beberapa bidang ilmu yang juga cukup dekat dengan studi diplomasi ekonomi antara lain bisnis \& keuangan internasional, manajemen \& pemasaran global dan komunikasi internasional/lintas budaya. Adanya variasi ini 
Economic Diplomacy as A Subject and Research Agenda: Practical, Conceptual and Methodological Issue

memungkinkan banyaknya riset kolaborasi yang bisa dilakukan oleh para peneliti diplomasi ekonomi.

Di Indonesia sendiri, riset terkait diplomasi ekonomi masih sangat jarang dan belum mendapatkan banyak perhatian meskipun secara praktik, pemerintah Indonesia telah banyak melakukannya. Ada beberapa riset yang cukup komprehensif terkait ini (lihat misal Killian 2012; Killian 2015; Sabaruddin 2016a; Sabaruddin 2016b; Delanova 2016), namun jumlahnya masih sangat terbatas. Sebagai ilustrasi, penelusuran menggunakan mesin pencari pada tanggal 21 Oktober 2020 dengan kata kunci 'economic diplomacy' menghasilkan 23,000 entri di Google scholar dan 953,000 di Google (1:41) sedangkan kata kunci 'diplomasi ekonomi' menghasilkan 735 entri di Google scholar dan 203,000 di Google (1:276). Hal ini menunjukkan bahwa untuk tiap 276 mention diplomasi ekonomi di Indonesia, hanya ada satu artikel ilmiah terkait ini, berbanding dengan satu artikel ilmiah untuk tiap 41 mention di luar Indonesia. Dengan kata lain, terdapat diskrepansi yang cukup besar antara diplomasi ekonomi sebagai kajian ilmiah dan isu populer di Indonesia dibandingkan dengan "economic diplomacy" sebagai kajian ilmiah dan isu populer di luar Indonesia. Ini berarti, masih sangat sedikit kajian ilmiah terkait diplomasi ekonomi di Indonesia, meskipun dalam interaksi/praktik popular telah banyak didiskusikan.

Sebagai penutup, dapat disimpulkan bahwa diplomasi ekonomi sebagai agenda riset masih memiliki banyak tantangan dan permasalahan utama yang mencakup isu praktis, konseptual dan metodologis. Tulisan ini telah berupaya mengurai kompleksitas dari riset-riset terdahulu mengenai diplomasi ekonomi dan mengusulkan beberapa upaya untuk mengatasi tantangantantangan ini, namun masih dibutuhkan lebih banyak riset tambahan terkait isu ini mengingat fenomenanyayang berkembang pesat.

\section{Simpulan}

Meningkatnya aktivitas ekonomi antar negara selama kurang lebih 30 tahun terakhir telah mendorong munculnya ketertarikan 
ilmiah terhadap fenomena ini dan memunculkan diplomasi ekonomi sebagai kajian tersendiri. Sayangnya sebagai suatu agenda riset baru, diplomasi ekonomi masih memiliki beberapa keterbatasan, khususnya dari segi konseptual, metodologis dan alat analisis. Jika dipecah lebih lanjut, keterbatasan ini mencakup belum adanya kesepakatan terkait definisi dan varian/ batasan serta adanya dikotomi dalam pendekatan dan metode penelitiannya yang menyebabkan kuatnya polarisasi keilmuan. Di satu sisi, banyaknya pendekatan dan metode yang digunakan untuk mengkaji diplomasi ekonomi akan bermanfaat untuk memperkaya bidang kajian ini, namun di sisi lain tanpa interaksi yang cukup di antara penstudinya, diplomasi ekonomi sebagai agenda riset justru akan mengalami polarisasi yang lebih jauh. Oleh karena itu, perlu ada upaya berkelanjutan bukan hanya untuk mendorong interaksi lintas disiplin yang lebih intensif, namun juga untuk 'menata' diplomasi ekonomi menjadi suatu agenda riset yang lebih sistematis.

\section{Referensi}

\section{Buku dan Bab dalam Buku}

Bayne, Nicholas. 2012. "Bilateral Economic Diplomacy: The United States", dalam Bayne, Nicholas, dan Stephen Woolcock (eds.), 2012. The New Economic Diplomacy: DecisionMaking and Negotiation in International Economic Relations. Hampshire: Ashgate Publishing.

Bayne, Nicholas, dan Stephen Woolcock, 2012. "What is Economic Diplomacy", dalam Bayne, Nicholas, dan Stephen Woolcock, (eds), 2012. The New Economic Diplomacy: DecisionMaking and Negotiation in International Economic Relations. Hampshire: Ashgate Publishing.

van Bergeijk, P.A.G., dan S.J.V. Moons, 2018. "Introduction to the Research Handbook on Economic Diplomacy", dalam van Bergeijk, P.A.G. (ed.), 2018. Research Handbook on Economic Diplomacy: Bilateral Relations in the Context of Geopolitical Change. Cheltenham: Edward Elgar Publishing. 
Economic Diplomacy as A Subject and Research Agenda: Practical, Conceptual and Methodological Issue

van Bergeijk, P.A.G., et al., 2011. "Economic Diplomacy: The Issues", dalam van Bergeijk, P.A.G., et al., (eds), 2011. Economic Diplomacy: Economic and Political Perspectives. Leiden: Martinus Nijhoff.

Berridge, G.R. dan Alan James, 2003. A Dictionary of Diplomacy 2nd edition. New York: Palgrave.

Drezner, D.W. 1999. The Sanctions Paradox: Economic Statecraft and International Relations. Cambridge: Cambridge University Press.

Lee, Donna, 1999. Middle Powers and Commercial Diplomacy: British Influence at the Kennedy Trade Round. London: Palgrave MacMillan.

Lee, Donna, dan Brian Hocking, 2010. "Economic Diplomacy", dalam Danemark, R.A. (ed.), 2010. The International Studies Encyclopaedia Vol. 2. Malden: Wiley-Blackwell.

Mastanduno, Michael, 2012. "Economic Statecraft" dalam Smith, Steve, et al., (eds.), 2012. Foreign Policy: Theories, Actors \& Cases. Oxford: Oxford University Press.

Okano-Heijmans, Maaike, 2016. "Economic Diplomacy" dalam Constantinou, C. M., et al. (eds.), 2016. The SAGE Handbook of Diplomacy. London: SAGE Publication.

Rana, Kishan S., 2012. "Economic Diplomacy: the Experience of Developing Countries", dalam Bayne, Nicholas, dan Stephen Woolcock, (eds), 2012 The New Economic Diplomacy: Decision-Making and Negotiation in International Economic Relations. Hampshire: Ashgate Publishing.

Rana, Kishan S., dan Bipul Chatterjee, 2011. "Introduction: The Role of Embassies", dalam Rana, Kishan S., dan Bipul Chatterjee (eds.), 2011. Economic Diplomacy: India's Experience. Jaipur: CUTS International. 
Tussie, D., 2013. "Trade Diplomacy", dalam Cooper, A.F., et al. (eds.), 2013. The Oxford handbook of modern diplomacy. Oxford: Oxford University Press.

Woolcock, Stephen, 2012a. European UnionEconomic Diplomacy: The Role of the EU in External Economic Relations. Surrey: Ashgate Publishing Company.

Woolcock, Stephen, 2012b. "Theoretical Analysis of Economic Diplomacy", dalam Bayne, Nicholas dan Stephen Woolcock (eds.), 2012. The New Economic Diplomacy: DecisionMaking and Negotiation in International Economic Relations. Hampshire: Ashgate Publishing.

\section{Jurnal dan Jurnal Daring}

Bayne, Nicholas, 2014. "Okano Heijmans M (2013) Economic Diplomacy Japan and the Balance of National Interests". Diplomacy \& Statecraft, 25 (3):575-577.

van Bergeijk, P.A.G., 1992. "Diplomatic Barriers to Trade", De Economist, 140 (1):45-64.

Blanchard, Jean-Marc F., dan Norrin M. Ripsman, 2008. "A Political Theory of Economic Statecraft". Foreign Policy Analysis. 4 (4):371-398.

Chen, X. dan Garcia, R.J. 2016. "Economic Sanctions and Trade Diplomacy: Sanction-busting Strategies, Market Distortion and Efficacy of China's Restrictions on Norwegian Salmon Imports", China Information, 30 (1):29-57.

Coolsaet, Rik, 2004. "Trade and Diplomacy: The Belgian Case". International Studies Perspectives. 5 (1):61-65. 
Economic Diplomacy as A Subject and Research Agenda: Practical, Conceptual and Methodological Issue

Delanova, Mariane, 2016. "Diplomasi Ekonomi Indonesia dan Negara-negara Berkembang dalam G-33 untuk Mempromosikan Proposal Special Products dan Special Safeguard Mechanism”, Jurnal Dinamika Global, 1 (01):1431.

Gardner, Richard N., 1985. "Sterling-Dollar Diplomacy in Current Perspective”, International Affairs, 62 (1):21-33.

Killian, P.M.E., 2012. "Paradigma dan Problematika Diplomasi Ekonomi Indonesia", Global Strategis, 6 (2): 170-185.

Killian, P.M.E., 2015. "Pemerintah Daerah dalam Diplomasi Ekonomi Indonesia: Studi Kasus pada Diplomasi Komersial Jawa Timur", Transformasi Global, 2(2): 20-40.

Lee, Donna, dan David Hudson, 2004. "The Old and New Significance of Political Economy in Diplomacy", Review of International Studies, 30 (3):343-360.

Mastanduno, Michael, 1999. "Economic Statecraft, Interdependence and National Security: Agendas for Research”, Security Studies, 9 (1-2):288-316.

Mastanduno, Michael, 1998. "Economics and Security in Statecraft and Scholarship”. International Organization. 52 (4):825854 .

Moons, S.J.V, dan P.A.G. van Bergeijk, 2017. "Does Economic Diplomacy Work? A Meta-Analysis of Its Impact on Trade and Investment", The World Economy, 40 (2):336-368.

Naray, Olivier, 2011. "Commercial Diplomats in the Context of International Business". The Hague Journal of Diplomacy, 6 (1):121-148.

Okano-Heijmans, Maaike, 2011. "Conceptualizing Economic Diplomacy: The Crossroads of International Relations, Economics, IPE and Diplomatic Studies". The Hague Journal of Diplomacy, 6(1):7-36. 
Okano-Heijmans, Maaike, 2012. “Japan's New Economic Diplomacy Changing Tactics or Strategy", Asia Pacific Review, 19 (1): 62-87.

Sabaruddin, S.S. 2016a. "Grand Design Diplomasi Ekonomi Indonesia: Sebuah Pendekatan Indeks Diplomasi Ekonomi”, Jurnal Ilmiah Hubungan Internasional, 12 (1): 69-90.

Sabaruddin, S.S. 2016b. "Penguatan Diplomasi Ekonomi Indonesia Mendesain Clustering Tujuan Pasar Ekspor Indonesia: Pasar Tradisional vs Pasar Non-Tradisional", Jurnal Ilmiah Hubungan Internasional, 12 (2):205-219.

Selmier, W. Travis, dan Chang Hoon Oh, 2013. "Economic Diplomacy and International Trade: Asean's Quest to ValueClaim”, World Economy, 36 (2):233-252.

Strange, Susan, 1970. "International Economics and International Relations: A Case of Mutual Neglect”, International Affairs, 46(2):304-315.

Stremlau, John. 1994. “Clinton's Dollar Diplomacy”, Foreign Policy, 97: 18-35.

Yakop, Mina, dan P.A.G. van Bergeijk, 2011. "Economic Diplomacy, Trade and Developing Countries", Cambridge Journal of Regions, Economy and Society, 4(2):253-267.

Zeng, Ka, 2016. "China's Free Trade Agreement Diplomacy", The Chinese Journal of International Politics, 9 (3):277-305.

\section{Dokumen Resmi}

Diplomatic Bluebook, 2019. Tokyo: Ministry of Foreign Affairs Japan. 
Economic Diplomacy as A Subject and Research Agenda: Practical, Conceptual and Methodological Issue

\section{Artikel Daring}

Australian Government Department of Foreign Affairs and Trade, 2020b. Five Pillars of the Economic and Commercial Diplomacy Agenda. Economic and Commercial Diplomacy: Connecting Australian Business to the World. [daring]. dalam https://www.dfat.gov.au/trade/engage/economicdiplomacy/Pages/five-pillars-of-the-economic-andcommercial-diplomacy-agenda [Diakses pada 1 September 2020].

Australian Government Department of Foreign Affairs and Trade, 2020a. Our History. About the Department. [daring]. dalam https://www.dfat.gov.au/about-us/department/Pages/ourhistory [Diakses pada 1 September 2020].

Eldora, Grace, 2020. "Indonesia Perkuat Diplomasi Ekonomi" BeritaSatu, 9 Januari [Daring]. dalam https://investor. id/international/indonesia-perkuat-diplomasi-ekonomi [Diakses pada 1 September 2020].

Government of Canada, 2019. "History of Global Affairs Canada. Global Affairs Canada" [daring]. dalam https://www. international.gc.ca/gac-amc/history-histoire/index. aspx?lang=eng [Diakses pada 1 September 2020].

Tempo, 2019. "Menlu Retno Sebut 4+1 Prioritas Politik Luar Negeri RI 2019-2024”, Tempo, 29 Oktober [Daring]. dalam https://dunia.tempo.co/read/1265955/menlu-retno-sebut41-prioritas-politik-luar-negeri-ri-2019-2024 [Diakses pada 1 September 2020].

World Trade Organization, 2019. "Regional Trade Agreements. How Many Regional Trade Agreements Have Been Notified to the GATT or the WTO" [Daring] dalam https://www. wto.org/english/tratop_e/region_e/region_e.htm\#facts [Diakses pada 11 Juli 2019]. 


\section{Lain-lain}

van Bergeijk, P.A. dan S. Moons, 2009. "Economic Diplomacy and Economic Security" (pp. 37-54) dalam New Frontiers for Economic Diplomacy, 16 Mei 2007. Lisbon: Instituto Superior de Ciências Sociais e Políticas.

Coolsaet, Rik, 2001. "Historical Patterns in Economic Diplomacy: From Protectionism to Globalisation, The Case of Belgium" dalam International Studies Association (ISA) 2001 Conference, 21 Februari. Chicago: International Studies Association.

Mdunge, Musa M., 2018. Chinese Economic Diplomacy in South Africa 1994-2015: A Partnership or a Chinese Neo-Colonial Endeavour?. Tesis Magister. Johannesburg, South Africa: Faculty of Arts Monash South Africa School of Social Sciences.

Moons, S.J.V. 2017. Heterogeneous Effects of Economic Diplomacy: Instruments, Determinants and Developments. Doctoral Dissertation. Rotterdam: International Institute of Social Studies Erasmus University Rotterdam.

Okamoto, Jiro, 1997. "Foreign Economic Policy Making in Australia: Analytical Framework and the Role of the State", Working Paper Series 96/97 No. 3, Maret. Institute of Developing Economies APEC Study Center

Rana, Kishan S., 2007. Economic Diplomacy Negotiations.

Saner, Raymond, dan Lichia Yiu, 2003. "International Economic Diplomacy: Mutations in Post-Modern Times". Discussion Papers in Diplomacy, No. 84, Januari 2003. Netherlands Institute of International Relations "Clingendael"

Yakop, Mina, dan P.A.G. van Bergeijk, 2009. The Weight of Economic and Commercial Diplomacy. Working Paper No. 478, Agustus. Institute of Social Studies. 
Economic Diplomacy as A Subject and Research Agenda:

Practical, Conceptual and Methodological Issue 